\title{
PALEOLOGY AND OLD HISTORY OF FOOTWEAR IN ROMANIA
}

\section{PALEOLOGIA ŞI ISTORIA VECHE A ÎNCĂLTĂMINTEI DIN ROMÂNIA}

\author{
Marlena POP* \\ INCDTP - Division: Leather and Footwear Research Institute, 93 Ion Minulescu St., Bucharest, Romania, e-mail: icpi@icpi.ro
}

\section{PALEOLOGY AND OLD HISTORY OF FOOTWEAR IN ROMANIA}

ABSTRACT. The degree of civilization for a people emerges out of the everyday life of its individuals, their way of dressing, dwelling, feeding, learning, living within a community, etc. "Everyday life" refers to the in actu civilization, that is, those civilization manifestations found in the everyday life of a human community, and the manner in which potential civilization facts (techniques and objects, all kinds of knowledge, social and moral rules) are converted into actual civilization facts. In this context, researching and outlining a history of footwear may be an act of knowledge in itself, but it can also be an addition to the history of the Romanian civilization. Romanian history sources, in terms of both arts and literature, and historiography and archeological sites, are poor and inadequate, particularly those regarding the old history of footwear. The paper presents a short history of footwear, from the late Paleolithic to the early Middle Age, on the Romanian territory of today. Both the material vestiges certifying leather processing and shoe making on the Romanian territory, and the Romanian linguistic treasure have equally revealed the millenary continuity of some trades, alongside the continuity of the Romanian people in the hearth of its Geto-Dacian ancestors.

KEY WORDS: footwear, paleology, history

\section{PALEOLOGIA ŞI ISTORIA VECHE A ÎNCĂLTĂMINTEI DIN ROMÂNIA}

REZUMAT. Măsura civilizaţiei unui popor nu este altceva decât viaţa cotidiană a indivizilor acestuia, felul lor de a se îmbrăca şi locui, de a se hrăni, de a se instrui, de a convieţui cu semenii etc. Prin „viaţa cotidiană” se înţelege civilizaţia in actu, adică acele manifestări de civilizaţie pe care le găsim în viaţa de toate zilele ale unei comunităţi umane, precum şi modul de convertire a unor fapte potenţiale de civilizaţie (tehnici şi obiecte, cunoştinţe de tot felul, norme sociale şi morale) în fapte de civilizaţie efective. În acest context, cercetarea şi conturarea unei istorii a încălţămintei poate fi un act de cunoaştere în sine, dar poate fi, la rândul său, o completare a paginii de istorie a civilizaţiei românilor. În România, sursele documentare sunt sărace şi nespecifice, mai ales în ceea ce priveşte istoria veche a încălţămintei, atât cele din arte şi literatură, cât şi cele din istoriografii, situri sau şantiere arheologice. Lucrarea prezintă o scurtă istorie a încălţămintei pe teritoriul României de astăzi, de la paleoliticul târziu până în evul mediu timpuriu. Atât vestigiile materiale care atestă prelucrarea pieilor şi confecţionarea încălţămintei pe teritoriul României, cât şi tezaurul lingvistic românesc relevă, în egală măsură, continuitatea multimilenară a unor meşteşuguri, deopotrivă cu însăşi continuitatea poporului român în vatra strămoşilor săi, geto-dacii.

CUVINTE CHEIE: încălţăminte, paleologie, istorie

\section{LA PALÉOLOGIE ET LA VIEILLE HISTOIRE DE CHAUSSURES EN ROUMANIE}

RÉSUMÉ. La mesure de la civilisation d'un peuple émerge de la vie quotidienne de ses individus, leur façon de s'habiller et de vivre, de se nourrir, de s'instruire, de vivre au sein d'une communauté etc. "La vie quotidienne" signifie la civilisation in actu, c'est-à-dire les manifestations de la civilisation qu'on trouve dans la vie quotidienne d'une communauté humaine, aussi que la manière de convertir des faits potentiels de la civilisation (les techniques et les objets, la connaissance de toutes sortes, les normes sociales et morales) dans des faits réels de la civilisation. Dans ce contexte la recherche et la définition d'une histoire de la chaussure peut être un acte de connaissance lui-même, mais il peut aussi compléter la page de l'histoire de la civilisation roumaine. En Roumanie, les sources documentaires sont rares et non spécifiques, en particulier en ce qui concerne l'histoire ancienne de chaussures, dans les arts et la littérature, ainsi que dans l'historiographie et les sites archéologiques. Cet article présente une brève histoire de chaussures dans le territoire actuel de Roumanie, depuis le Paléolithique et jusqu'à la fin du Moyen Age. Les vestiges matériels attestant le traitement du cuir et la fabrication de chaussures en Roumanie, ainsi que le thésaurus linguistique roumain révèlent également la continuité millénaire de l'artisanat et la continuité du peuple roumain dans le foyer de ses ancêtres, les Geto-Daces.

MOTS CLÉS: chaussure, paléologie, histoire

\section{INTRODUCTION}

Anthropogenic evidence was found on the Romanian territory, on the river borders in the Middle Carpathian Mountains, including quartz tools, specific to the oldest Paleolithic culture. A dwelling ensemble with a lot of tools and fossil mammoth remains belonging to Mousterian hunters dating from the Middle Paleolithic period was found in Ripiceni,

\section{INTRODUCERE}

Pe teritoriul României au fost descoperite mărturii ale procesului de antropogeneză, aşa cum sunt cele de pe văile râurilor din Carpaţii Meridionali - unelte de cremene tipice pentru cele mai vechi culturi paleolitice. Datând din paleoliticul mijlociu, la Ripiceni, Botoşani, sa descoperit un complex de locuire bogat în unelte şi resturi fosile de mamut, care au aparţinut vânătorilor 
Botoşani County. These housings look like the dwelling sites in Olduvai, Africa, Terra Amata and Lazaret cave in France.

\section{Footwear in the Paleolithic Period}

Of the Late Paleolithic period more bone tools, specific for hide processing, and shoe and garment making were found, such as slivers, scrapers, chisels and prickers.

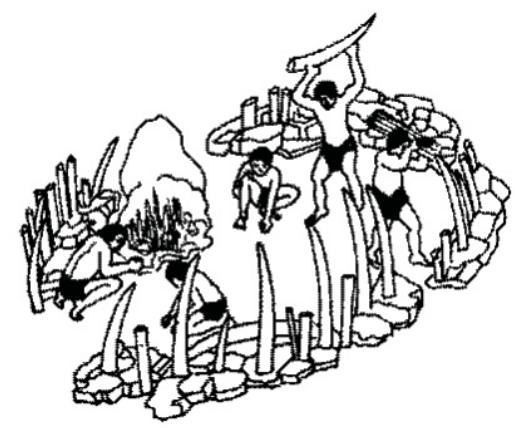

Figure 1. Drawing of wind shelters

Figura 1. Schiţa adăposturilor de vânt

\section{Footwear in the Neolithic Period}

Material and artistic culture of that period has shown archeological evidences of footwear specific for the Romanian Neolithic culture. Such objects were found in Boian, Gumelniţa, Hamangia, Cucuteni. Most of the things found in Gumelniţa are made from clay, which is common for the Neolithic cultures; the bone statuettes are a specific trait of Gumelniţa civilization, and, even though bone objects were also found in other cultures (e.g. Cucuteni), they are not as many and as diverse as the former.

With the increased number of bone tools, copper awls started to appear, which were more effective. The bone or metal tools are thought to be used in making footwear from thick hides, leather bags, fur caps and coats and some hide vessels for carrying water and salt. As early as in Neolithic period, awls with copper needle and bone handle, others with timber handle have been found in Verbicioara Sălcuţa culture [2].

The Neolithic art also preserves some clothing elements of those times reflected in the statuettes and anthropomorphous ceramics. The best known ones are from Boian, Gumelniţa, Cucuteni and Hamangia. The musterieni. Aceste adăposturi sunt asemănătoare complexelor de locuire de la Olduvai, Africa, Terra Amata şi peştera Lazaret din Franţa.

\section{Încălţămintea în paleolitic}

Din paleoliticul superior s-au păstrat multe unelte din os, specifice prelucrării pieilor şi confecţiei încălţămintei şi îmbrăcămintei din piele, cum ar fi: aşchii, răzuitori, dălţi, împungători.

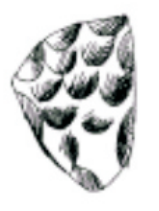

Figure 2. A scraper from the Paleolithic - Ripiceni Figura 2. Răzuitoare din paleolitic - Ripiceni

\section{Încălţămintea în neolitic}

Cultura materială şi cea artistică din acea perioadă fac referire şi la mărturiile arheologice ale încălţămintei specifice culturii neolitice româneşti. Acestea sunt reprezentate de piesele din culturile Boian, Gumelniţa, Hamangia, Cucuteni. Majoritatea pieselor gumelniţene sunt modelate din lut, fapt obişnuit pentru toate civilizaţiile neoeneolitice. În schimb, figurinele de os reprezintă o trăsătură originală a civilizaţiei gumelniţene şi, chiar dacă piese de os se întâlnesc şi în alte culturi (ex. Cucuteni), ele sunt departe de numărul şi diversitatea tipologică a celor gumelniţene.

În acelaşi timp cu sporirea instrumentarului de os, încep să apară şi sulele de cupru, unelte mult mai eficace în muncă. Se consideră că uneltele - de os sau metal - erau folosite „la pregătirea încălţămintei din piei groase, la confecţionarea burdufelor, căciulilor, cojoacelor şi a unor vase de piele, care transportau apă şi sare. În mod deosebit se remarcă prezenţa încă din neolitic a sulei cu ac de aramă şi mâner de os - alte exemplare având probabil mânerul de lemn-descoperită la Verbicioara-cultură Sălcuţa" [2].

Arta neolitică păstrează şi ea, datorită statuetelor şi ceramicii antropomorfe, elemente de vestimentaţie ale epocii. Cele mai renumite sunt cele de Boian, Gumelniţa, Cucuteni, Hamangia. Vasele antropomorfe 
number and artistic quality of the anthropomorphous vessels exceed those of other Neolithic civilizations. depăşesc prin număr şi calitate artistică realizările celorlalte civilizaţii eneolitice.

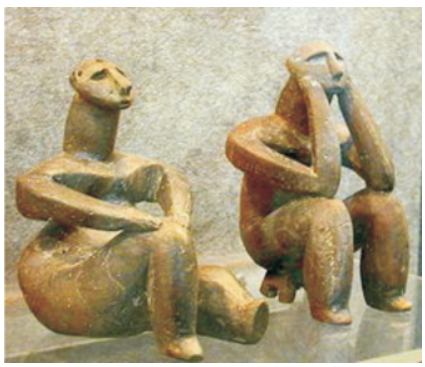

Figure 3. "The Thinker" statuettes (Hamangia culture)

Figura 3. Statuete „Gânditorul” (cultura Hamangia)

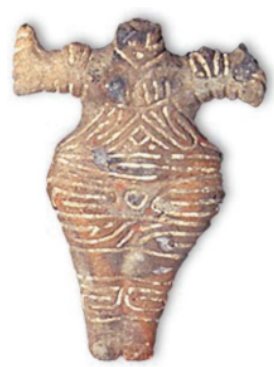

Figure 4. Worship statuette (Boian culture)

Figura 4. Statuetă de cult (cultura Boian)

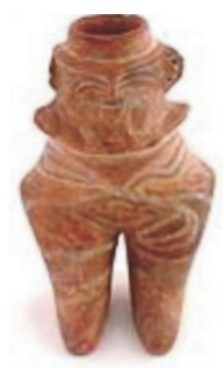

Figure 5. Statuette - Gumelniţa Figura 5. Statuetă - Gumelniţa
The study on footwear representation in the Neolithic art in Romania has revealed that the foot without toes stands for a shod foot. At Tîrpeşti, Neamţ County, the feet of anthropomorphous vessel or large statuette of the Precucuteni culture have revealed the footwear of those times to be high boots with high vamps. The "moccasin" representations found in Ghelăieşti, Neamţ County (Cucuteni culture) are particularly interesting and were the basis for footwear representations in some Neolithic cultures such as Gumelniţa (Vidra, Căscioarele, Sultana and Plosca) or Sălcuţa, reported by Korner Th. (1932, 1944) (Figures 3-5).

While the statuette foot discovered at the site of the Precucuteni culture in Traian has revealed the "calceus" footwear; and the "moccasins" found in Ghelăieşti are tightly fit to the foot and have the high vamp opened in front, above the ankle. The clay foot found in Plosca, Teleorman County, shows a particularly stylish boot which would stir designers' appreciation even nowadays. The lasts and human foot mouldings found in Gumelniţa are a unique discovery for the history of footwear making (Figures 6-8).
Studiul efectuat asupra reprezentărilor de încălţăminte în plastica neolitică din România a reliefat faptul că piciorul uman fără redarea degetelor înfăţişează piciorul încălţat. La Tîrpeşti - Neamţ, picioarele de vase antropomorfe sau de statuete de mari dimensiuni, aparţinând culturii Precucuteni, înfăţişează încălţămintea vremii, sub aparenţa unor cizmuliţe cu un carâmb înalt. Deosebit de interesante sunt reprezentările de „mocasini” de la Ghelăieşti - Neamţ (cultură Cucuteni), care au stat la baza interpretării a numeroase alte reprezentări de încălţăminte din culturile neolitice de tip Gumelniţa (la Vidra, Căscioarele, Sultana şi Plosca) sau de tip Sălcuţa, exemple citate în literatura de specialitate de Korner Th (1932, 1944) (Figurile 3-5).

În timp ce piciorul de figurină aflat în aşezarea culturii Precucuteni de la Traian redă plastic încălţămintea de tip „calceus", iar la Ghelăieşti „mocasinii” cucutenieni sunt figuraţi mulând perfect laba piciorului şi având căputa înaltă deschisă în faţă deasupra gleznei; piciorul de lut de la Plosca - Teleorman înfăţişează o încălţăminte de tipul unei „ghete" de o eleganţă şi sobrietate marcante, care şi azi ar putea stârni admiraţia designerilor. O descoperire unică pentru istoria confecţiei încălţămintei o reprezintă calapoadele şi mulajele luate după piciorul uman, de la Gumelniţa (Figurile 6-8). 


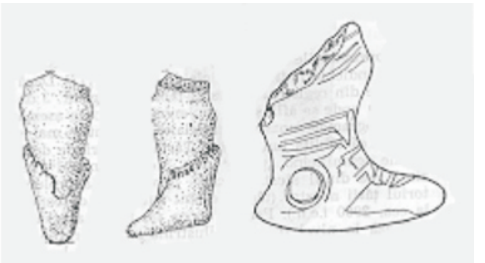

Figure 6. Moccasin of Cucuteni and Gumelniţa boot Figura 6. Mocasin de Cucuteni şi gheată de Gumelniţa

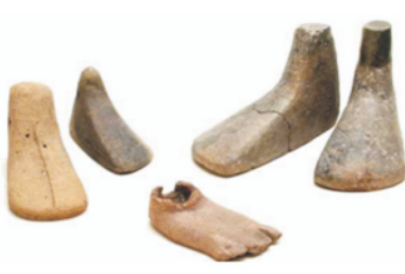

Figure 7. Lasts and footwear moulds

(Gumelniţa culture -

Museum of Lower Danube, Călăraşi)

Figura 7. Calapoade şi matriţe pentru încălţăminte

(cultura Gumelniţa -

Muzeul Dunării de Jos, Călăraşi)

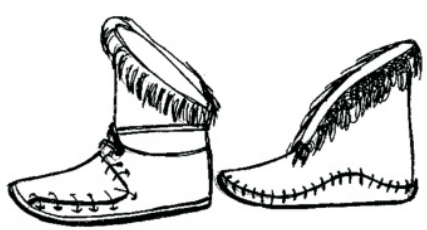

Figure 8. Drawings reproducing footwear drawn on the Gumelniţa vessels

Figura 8. Schiţe de reconstituire după vase - Gumelniţa

\section{Footwear in the Bronze and Iron Ages}

The thriving Thracian culture in the Bronze Age (2,000-1,200 B.C.) has bequeathed a rich experience in hide processing and making leather and fur garments, and increasingly used metal tools (brass and bronze), which were easy to handle and more efficient, in addition to the bone and stone ones. Among the Bronze Age ceramic items of the Monteoru culture, a boot-shaped cup with a welt, an upwardly bent oval toe cap and a vamp decorated with lines and triangles, was found in Cernăteşti. This kind of shoes with bent toe caps has been also found in the Hittite world, and boot-like cups also appeared in Etruscan, Hellenistic and Roman cultures.

\section{Epoca bronzului şi a fierului}

Înfloritoarea civilizaţie tracică din epoca bronzului (2.000-1.200 î.e.n.) a lăsat moştenire în timp bogate tradiţii în domeniul prelucrării pieilor şi confecţionării vestimentaţiei din piele şi blană, pe lângă uneltele tradiţionale de os şi piatră, şi a introdus tot mai mult în practica zilnică uneltele de metal (aramă şi bronz), mai lesnicioase la mânuit, mai eficace şi mai precise în executarea complexelor operaţii. Printre obiectele ceramice din epoca bronzului, în cultura Monteoru, la Cernăteşti, s-a descoperit o ceşcuţă în formă de "cizmuliţă" cu ramă la talpă, cu vârf oval îndoit brusc în sus şi cu căpută împodobită cu şiruri de liniuţe şi triunghiuri. Astfel de încălţări cu vârf arcuit se întâlnesc şi în lumea hitiţilor, dar "cizmuliţe-ceşcuţe" apar în alte civilizaţii etruscă, elenistică şi romană - cu mult mai târziu.

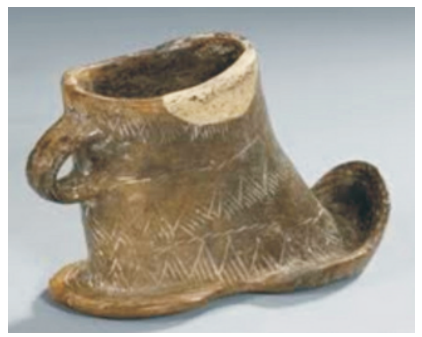

Figure 9. Boot-shaped cup, Cernăteşti, Monteoru culture

Figura 9. Ceşcuţa-cizmuliţă de la Cernăteşti, cultura Monteoru 


\section{DACIAN AND DACIAN-ROMAN FOOTWEAR}

\section{The Dacian-Getic Period}

Beginning with the Iron Age, the Southern Thracians, Northern Thracians (Geto-Dacians), and Illyrs in the West appeared. Under the increasingly higher social stratification conditions and finally during the centralized and united Dacian state governed by Burebista (about 82-44 B.C.), two cultural features appeared and developed: a folk aspect and a "princely" one, which were also revealed in the leather products. Among the folk products, Vasile Pârvan listed "harnesses, sheepskin coats, fur caps, peasant sandals", saying that "they were all made by men", meaning that it was a specific men's craft.

The Dacian prisoners shown at Adamclisi [7] wore fur coats with fur lining, well cut, following the body shape. They also used to wear tight peasant trousers and peasant sandals.

\section{ÎNCĂLTĂMINTEA DACICĂ ŞI DACO-ROMANĂ}

\section{Perioada daco-getică}

Începând cu epoca fierului, se individualizează etno-cultural tracii de sud, tracii de nord (geto-dacii) iar la vest, ilirii. În condiţiile stratificării sociale tot mai accentuate şi, în cele din urmă, a constituirii statului dac centralizat şi unitar condus de Burebista (cca. 82-44 î.e.n.), în ansamblul civilizaţiei dacice s-au conturat şi detaşat tot mai mult un aspect popular al culturii şi un aspect „princiar”, aulic, sesizabile şi în produsele de piele. În rândul produselor populare, Vasile Pârvan includea: „hamuri, cojoace, şube, căciuli, opinci etc.", despre care spunea că "toate erau treaba bărbaţilor", în sensul practicării unui meşteşug specializat, bărbătesc.

Sumane sau şube, „care, ca şi azi, aveau blană pe dinăuntru şi erau destul de bine croite pe trup", poartă prizonierii daci la Adamclisi [7]. Picioarele erau încălţate cu opinci şi cioareci.
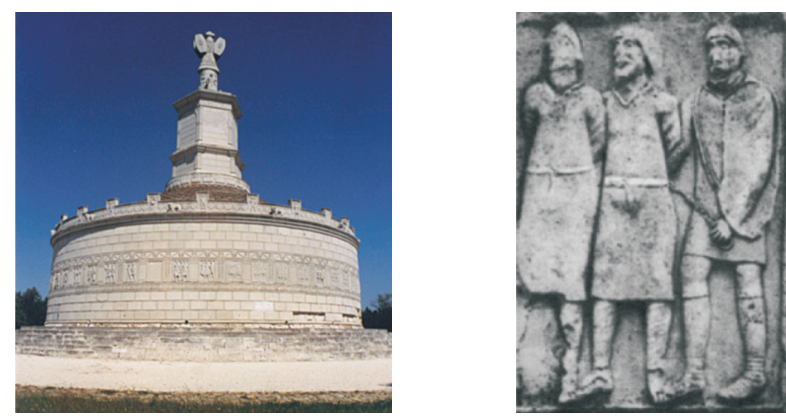

Figure 10. The memorial and metope of Adamclisi

Figura 10. Metopa şi monumentul de la Adamclisi

There were seven kinds of Geto-Dacian footwear, revealed both in aboriginal and Roman sources: peasant sandals, celebration footwear, high-heeled and embroidered women's shoes, low boots, buskins, heeled shoes and Decebal's calceus. Dacians used to attach iron spurs on the adequate footwear. Celebration footwear had leather soles and cloth or felt uppers and were the Dacian correspondent to the Roman pero, covering the ankle, but less usual than the Roman perones. They can be seen on Traian's Column and Adamclisi memorial, sometimes with an aesthetically laced and cut vamp.
Încălţămintea geto-dacilor, în variate ilustrări antice, atât autohtone, cât şi romane, înfăţişează şapte tipuri distincte: opinci, călţuni, conduri, botine, coturni, încălţări cu toc şi calceus-ul decebalian. Pe încălţări adecvate dacii ataşau pinteni de fier. Călţunii, atestaţi în Dacia - ca şi opincile - încă din neolitic, putând avea numai talpă din piele, iar faţă din pâslă sau postav, reprezintă omologul dacic al pero-ului roman comun, învelind glezna, mai puţin uzual însă decât perones, la romani. Călţunii îi întâlnim pe Columna Traiana şi la Adamclisi, uneori cu despicătura căputei, estetic dantelată. 


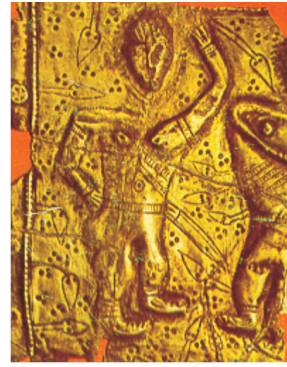

Figure 11. Decorated plate of a Dacian belt on which leather low boots and Dacian flag can be seen

Figura 11. Placa unui chimir dacic, pe care se remarcă botinele şi steagul dacic

Women's high heeled shoes - with the toe cap bent outwardly - are similar to the footwear of Hittites, Persians, Etruscans. Peasant sandals with toe caps directed upwardly as in the low boots are found in the Thracian Bronze Age. This kind of footwear can be seen in the priestly people represented on the gold helmet found in Băiceni, laşi County. Low boots can be also seen, worn by the three women on a cup found in Popeşti, Ilfov County. Boot quarters are lower than those of high boots worn by the Bendis goddess - worshiped by Thracians and Geto-Dacians, shown on a Greek relief of the $4^{\text {th }}$ century B.C., and higher than the short boot quarters worn by Roman goddess Diana of Juc (Bendis).

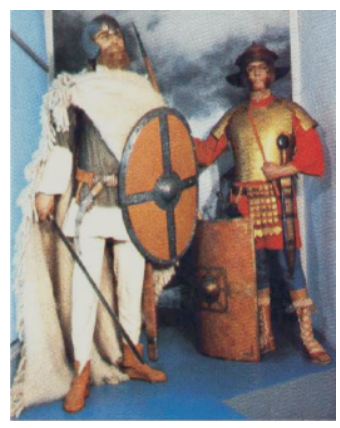

Figure 13. Dacian and Roman soldiers' reconstituted suits

Figura 13. Reconstituire costum soldat dac şi soldat roman

Buskins, popular among the Greeks, as early as Homer's period $\left(12^{\text {th }}-8^{\text {th }}\right.$ centuries B.C. $)$, were introduced in the theatre by Aeschylus, providing tragedians with an impressive appearance when

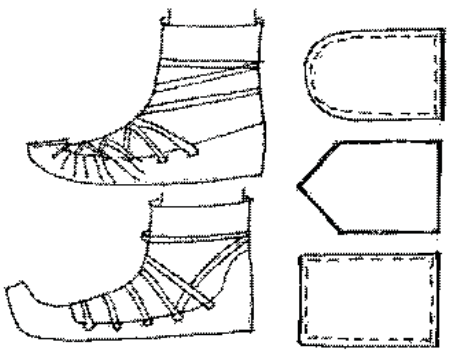

Figure 12. Drawings of the footwear presented on the Adamclisi memorial

Figura 12. Schiţe de reconstituire a încălţămintei reprezentate pe monumentul de la Adamclisi

Condurii - cu bot specific, încovoiat în sus - evocă încălţămintea hitită, persană, etruscă. Opincile cu gurgui mare, carenat, întors în sus, ca vârful botinei din epocă, aparţine epocii bronzului tracic. Pe obrazul coifului de aur de la Băiceni - laşi, personalul sacerdotal poartă asemenea conduri. Rolul lor pare a fi fost de atribut cultural. Botinele se repetă perechi la cele trei figuri feminine redate ritual, cultic, pe o cupă de la Popeşti - Ilfov. Ca înălţime, carâmbii botinei sunt între carâmbii cizmei zeiţei Bendis - adorată la traco-getodaci - redată pe un relief grec din sec. IV î.e.n. şi carâmbul scurt al botinei Dianei romane de la Juc (Bendis).

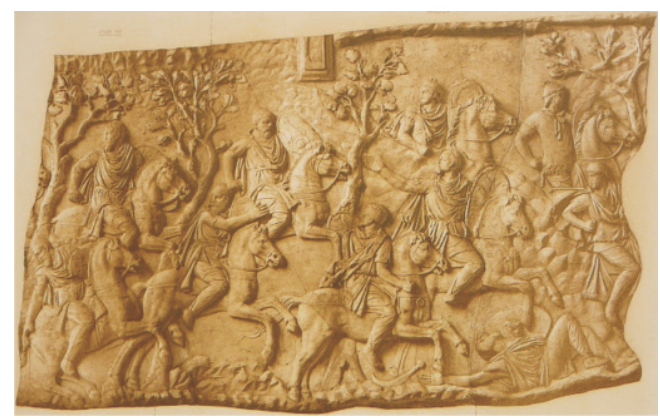

Figure 14. Fragments on the Traian's Column Bas-reliefs showing Dacian wars

(101-102 and 105-106 A.D.)

Figura 14. Fragmente de pe columna lui Traian basoreliefuri reprezentând războaiele dacice (101-102 e.n. şi 105-106 e.n.)

Coturnii, în vogă la „conturnaţii ahei” încă din epoca grecilor lui Homer - sec. XII-VIII î.e.n., introduşi de Eschil în teatru, dând prestanţa tragedienilor în interpretarea de zei şi eroi, reprezintă în Dacia o 
playing gods and heroes, and were brought into Dacia by Greeks via Pontic towns or from the South by the Thracians.

Decebal's calceus is distinguished by its sobriety and smartness. Such footwear, tight on the feet, as high as a short boot and closed in front with two bands and a button making three loops can be seen on the Traian's Column. The king was wearing such footwear in his last moments, giving him a princely effect.

Footwear - attribute of an advanced civilization reveals, in the Geto-Dacian people, clothing differences expressing hierarchy, social condition, customary law. As early as the $5^{\text {th }}$ century B.C., Herodotus (Histories, VII, 75) reported footwear made from deer skin (pedila hebron) worn by Thracians; deer and stag were symbols of the Dacian goddess Bendis (6).

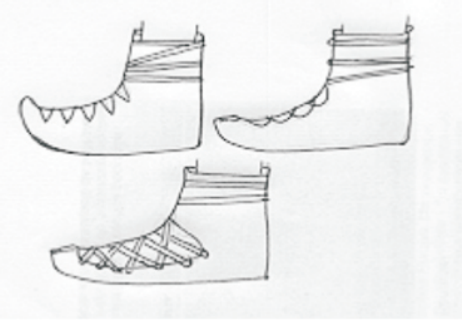

Figure 15. Dacian peasant sandals, $1^{\text {st }}-2^{\text {nd }}$ century A.D. Figura 15. Tipuri de opinci dacice, sec. I-II e.n.

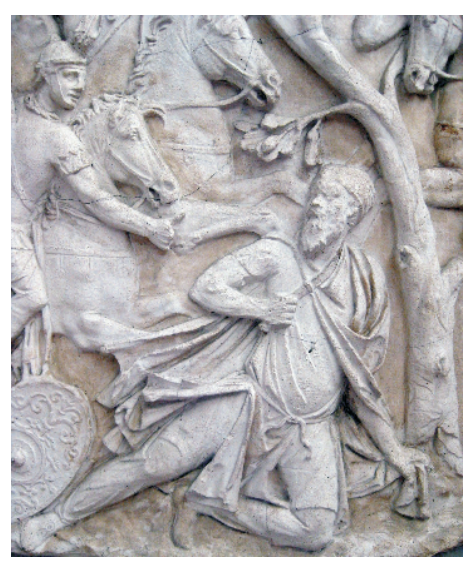

Figure 17. Traian's Column (Rome) - Decebal dying Figura 17. Columna lui Traian (Roma) - Decebal murind

\section{The Dacian-Roman Period}

The tomb monument sculptures in the Roman province of Dacia Felix reveal a lot of leather products intended for various uses - clothing and accessories apariţie insolită, aport elen prin oraşele pontice sau filiera sud tracică.

Calceus-ul decebalian se distinge prin ţinută sobră şi elevată. Columna Traiana îl redă bine mulat pe picior, înalt cât o gheată şi încheiat în faţă prin două legături şi un bumb, formând trei ochiuri în lanţ. Aspectul său degajă un efect princiar. Astfel apare înveşmântat regele-erou în ultima clipă de viaţă.

Încălţămintea - apanaj al civilizaţiei avansate evidenţiază la geto-daci, la fel ca şi în alte culturi antice, diferenţieri vestimentare potrivit ierarhiei, poziţiei sociale, cutumelor socio-culturale. Încă din sec. V. î.e.n., Herodot (Istorii, VII, 75) semnala la tracii bitini „încălţăminte din piele de căprioară” (pedila hebron) - cerbul şi căprioara erau atribute ale zeiţei dacice Bendis [6].

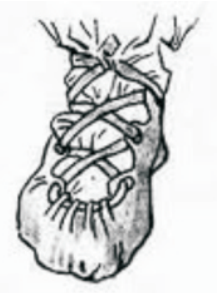

Figure 16. Dacian calceus, $1^{\text {st }}$ century A.D.

Figura 16. Calceus dacic, sec. I e.n.

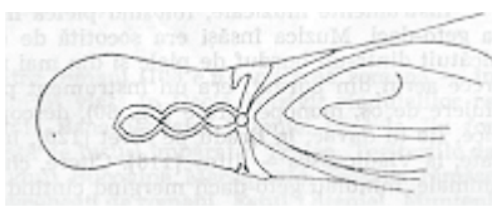

Figure 18. King Decebal's calceus

Figura 18. „Calceusul” regelui Decebal

\section{Perioada daco-romană}

Un impresionant număr de produse din piele, având cele mai diverse destinaţii şi utilităţi - veşminte şi accesorii vestimentare, de regulă - înfăţişează în sculpturile lor monumentale funerare din provincia 
such as sheepskin coats, fur hats, various belts, ribbons and straps, bags, a large variety of shoes, decorated harness, saddles and saddle girths, a tympanum (tambourine with animal skin membrane, fastened on the shoulders by two straps), etc.; all these show the Roman way of life-more romano. Aboriginal garment with details on autochthonous costumes are also shown, thus certifying the preservation of the Dacians' costumes.

A woman's tomb found in Callatis (Mangalia Dobrogea) contained a particularly rich inventory, where among other things there were 6 pairs of shoes (two pairs of sandals and four pairs of boots). On some leather fragments, the gold dye decoration can still be seen today.

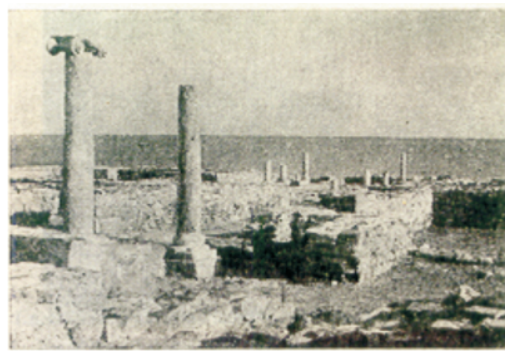

Figure 19. Callatis - Rich residential area, $2^{\text {nd }}$ century A.D.

Figura 19. Callatis - Zona caselor bogate, sec. al II-lea e.n.

Bronze statues also reveal a large variety of footwear. Caliga - a high boot with leather gaiters (corrigae) was found in Apulum - Alba lulia and Romula/Malva - Reşca. The statue fragment in Sarmizegetusa reveals a sandal (sandalium, solea). As with other clothing elements, the Romans' footwear revealed the differences between social classes, hierarchical positions and economic conditions.
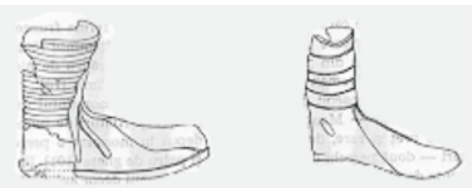

Figure 21. Caliga - high boot, Apulum Caliga of Romula Figura 21. Caliga-cizmă, Apulum Caliga de la Romula romană Dacia Felix: cojoace, căciuli, diferite centuri, cordoane şi curele, pungi de piele, încălţăminte de diferite tipuri, apoi frâie şi hamuri ornate cu aplici şi pendantivi, şei pe cai şi chingi, un timpanum (tamburină cu membrană din piele, prinsă pe umeri cu două curele etc.), ansamblul acestora ilustrând modul de viaţă roman - more romano. Alte reprezentări însă redau elemente de îmbrăcăminte băştinaşă şi diferite amănunte ale portului autohton, atestând şi în acest mod continuitatea dacilor în epoca romană, păstrarea în uz a portului strămoşesc.

Un inventar deosebit de bogat conţinea mormântul unei femei de la Callatis - Mangalia, în Dobrogea. Alături de numeroase obiecte de preţ şi foarte rare, defunctei $\mathrm{i}$ s-au depus în mormânt 6 perechi de încălţăminte două perechi de sandale şi patru de ghete. Pe unele fragmente de piele se poate admira şi azi decorul aplicat cu vopsea aurie, cu motive geometrice.

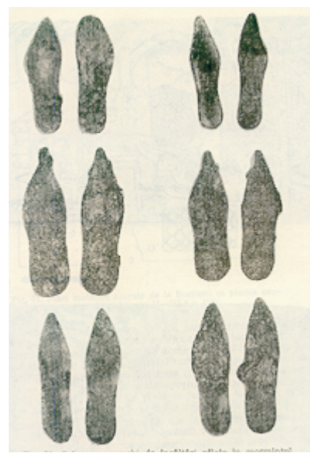

Figure 20. Archaeological footwear - a rich woman's grave in Callatis (Mangalia), $2^{\text {nd }}-3^{\text {rd }}$ century A.D.

Figura 20. Încălţăminte arheologică - mormântul unei femei bogate din Callatis sec. II-III e.n.

Arta statuară în bronz redă şi ea tipuri de încălţăminte. Caliga-cizmă, cu jambiere de piele (corrigae), atestată la Apulum - Alba Iulia şi la Romula/Malva - Reşca. O sandală (sandalium, solea) arată fragmentul statuar de la Sarmizegetusa. Ca şi alte elemente de vestimentaţie, încălţămintea marca la romani deosebiri între diferite clase sociale, funcţii ierarhice, stări economice.

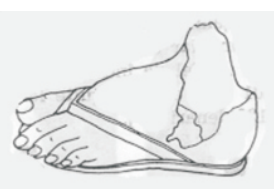

Figure 22. Sandal from Sarmizegetuza Figura 22. Sandala de la Sarmizegetusa 
When the old Dacian-Roman urban centers were destroyed by the migrating peoples, in the $4^{\text {th }}-7^{\text {th }}$ centuries A.D., the productive forces were moved to the country side and trades became prevailingly domestic as the country community was the major organizing form. Corporate bodies were still maintained, and this is revealed by the chain with pendants found in Şimleul Silvaniei, Zalău County.

Tools found in various sites in our country have revealed the development and continuity in hide and fur processing and shoe making trades. Various furrier's tools such as short and wide knives have been also found in Târgşor ( $4^{\text {th }}$ century A.D.) and Sucidava ( $4^{\text {th }}$ $5^{\text {th }}$ centuries A.D.). Curved knives, an advanced type of knives, have been found in Pietroasa ( $4^{\text {th }}$ century A.D.) and Budureasca, Prahova County $\left(5^{\text {th }}-6^{\text {th }}\right.$ centuries A.D.).

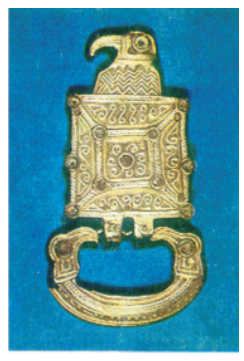

Figure 23. Buckle found in Fundătura, Cluj ( $3^{\text {rd }}$ century A.D.)

Figura 23. Cataramă de la Fundătura, Cluj, sec. III Cluj, sec. 11 (

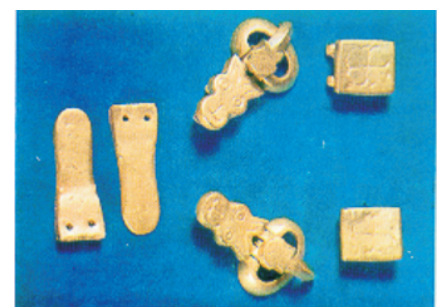

Figure 24. Bronze buckles for footwear found in Histria ( $6^{\text {th }}$ century A.D.)

Figura 24. Catarame din bronz, pentru încălţăminte -

Histria, sec. VI
În condiţiile destrămării vechilor centre urbane daco-române, ale distrugerilor provocate de migratori, în sec. IV-VII e.n. se constată dispersarea forţelor de producţie în teritoriul rural, unde obştile săteşti devin forma principală de organizare, meşteşugurile căpătând un caracter precumpănitor casnic. Se păstrează, totuşi, puternice tradiţii ale antichităţii târzii (ale breslelor de meşteşugari), pe care le atestă cunoscutul lanţ cu pandantivi - unelte miniaturale - de la Şimleul Silvaniei - Zalău.

Uneltele descoperite în diferite locuri din ţară relevă continuitatea şi dezvoltarea meşteşugurilor pielăriei, cojocăriei şi cizmăriei. Cuţite de fier scurte şi late s-au aflat la Târgşor (sec. IV e.n.) şi Sucidava (sec. IV-V e.n.). Cuţite - de tipul Şimleu - cu lama curbată „păstaie” sunt atestate la Pietroasa (sec. IV e.n.) şi la BudureascaPrahova (sec. V-VI e.n.), unde tipul uneltei apare evoluat.

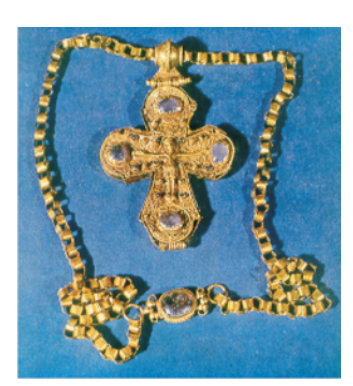

Figure 25. Pendant found in Coşoveni ( $4^{\text {th }}$ century A.D.)

Figura 25. Pandantiv Coşoveni, sec. IV e.n.
Leather products made in the workshops in the Roman-Byzantine empire, reported by Maurikios, were high quality objects of daily or particular use. Such workshops made red dyed leathers that were given as gifts to the Barbarians, as reported by Priscus. The relationship between this empire and Dacian-Roman people promoted the transmission of advanced techniques and processes for that age to the north of the Danube.

\section{The First Christian Evidence}

In the $4^{\text {th }}$ century, Romanization continued in the areas owned by the Romans (Banat, S-W Oltenia, Dobrogea) or those just conquered (the $4^{\text {th }}$ century)
Produsele din piele lucrate în imperiu denotă calităţi superioare, demne de renumele atelierelor româno-bizantine ce confecţionau numeroase obiecte de trebuinţă zilnică sau specială, menţionate îndeosebi de către Maurikios. Din aceste ateliere plecau, ca daruri către barbari, piei vopsite în roşu, amintite de Priscus. Relaţiile dintre daco-romani şi imperiu favorizau transmiterea la nord de Dunăre a unor tehnici şi tehnologii avansate pentru epoca lor.

\section{Primele mărturii creştine}

În sec. IV zonele rămase în stăpânirea romanilor (Banatul, SV Olteniei, Dobrogea) sau cele intrate acum (sec. IV e.n.) (capetele de pod de pe malul stâng al 
(the bridge on the left Danube border in Turri, Constantiniana-Daphne, Barboşi). As the formal language in the orthodox churches was Greek, the first Romanian churches built with the marble of Sarmizegetusa Regia (churches of Densuş and Ştei, the $6^{\text {th }}-8^{\text {th }}$ centuries), architecture, decorations and objects were of Byzantine style with Greek inscriptions. The Bible pictures and teachings were represented by the image of the natives, as it is usual in the orthodox iconography. Thus, in the very old church in Densus, where fragments of the old painting are preserved, some clothes and footwear specific for the free Dacians, who preserved the Dacian culture out of the Roman empire, may be seen. The low leather boots worn by tarabostes - Dacian aristocrats, peasant sandals worn by the free people and the slaves' naked feet can also be seen.

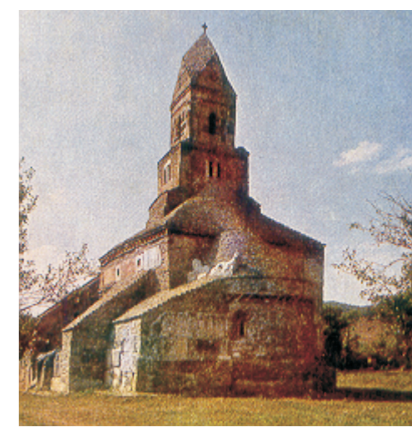

Figure 26. The church of Densuş - the first Romanian orthodox church, $7^{\text {th }}$ century A.D.

Figura 26. Biserica de la Densuş - prima biserică otodoxă din România, sec. VII e.n.

The Early Middle Ages saw the last massive population migrations from East Asia. Due to the invasions of migratory people there are less material culture vestiges than in the previous periods of historical and economical-social stability. Even so, in many residences of those times, tools for hide processing, and for footwear and clothes making have been found. Monks' footwear was made of a wooden sole onto which thin leather strips were braided. The peasant sandal, the Dacian calceus, remained the main footwear of the Romanian population, both in the summertime and in winter. Thus it was proved that, in the $6^{\text {th }}-8^{\text {th }}$ centuries A.D., footwear was made in individual residences, according to the people's economic power.
Dunării de la Turri, Constantiniana-Daphne, Barboşi) au participat la continuarea procesului de romanizare. Datorită faptului că în imperiul Roman limba oficială era greaca, în primele mănăstiri, schituri şi biserici ortodoxe româneşti, cele construite cu marmură de la Sarmizegetusa Regia, respectiv bisericile de la Densuş şi Ştei, sec. VI-VIII e.n., arhitectura, picturile murale şi obiectele bisericeşti erau în stil bizantin şi cu inscripţionări greceşti. Aşa cum este obiceiul în iconografia ortodoxă, imaginile şi învăţăturile biblice erau reprezentate de imaginea omului locului. De aceea, în biserica de la Densuş, unde se mai păstrează fragmente din vechea pictură, se vor observa veşminte şi încălţăminte specifice dacilor liberi, cei care au continuat cultura dacică, în afara spaţiului imperial roman. Se remarcă încălţămintea din piele, tip botină, atât de des folosită de „tarabostes”, nobilii daci, alături de opinca oamenilor liberi şi piciorul gol al sclavului.

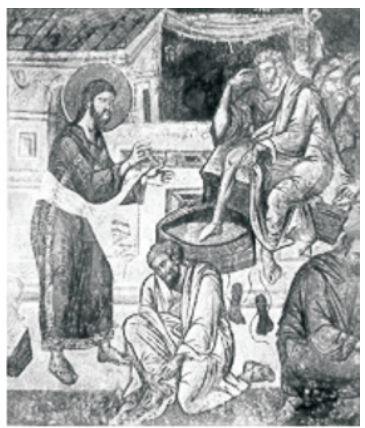

Figure 27. Mural painting (restored) in the church of Densuş

Figura 27. Pictură murală din interiorul bisericii de la Densuş (restaurare)

Evul Mediu Timpuriu înregistrează ultimele mişcări masive de populaţie venite dinspre estul asiatic. Datorită invaziilor popoarelor migratoare, vestigiile culturii materiale sunt mult mai puţine decât în perioadele de stabilitate istorică şi implicit economicosocială, din epocile anterioare. Cu toate acestea, în toate locuinţele vremii s-au descoperit unelte de prelucrare a pieilor şi de confecţie a îmbrăcămintei şi încălţămintei din piele. Încălţămintea călugărilor era formată dintr-o talpă din lemn pe care se împleteau nişte nojiţe de piele. Opinca, calceus-ul dacic, a continuat să rămână încălţămintea principală a populaţiei româneşti, atât vara, cât şi iarna. Astfel se demonstrează că în sec. VI-VIII e.n. încălţămintea se confecţiona în cadrul gospodăriilor individuale, în funcţie de puterea economică ale acestora. 
In the archeological sites of Capidava - Constanţa County, Vaslui - Moldova, Dăbâca - Cluj, Alba-lulia or Noslac - Transilvania, increasingly improved tools, as well as a miner's sheepskin coat and a peasant sandal have been found, certifying the continuity of trades such as hide processing and leather clothing and footwear making.

In addition to the material culture, the treasure of the Romanian language also provides precious evidence regarding the essential terms related to leatherworking, clothing and footwear making. There are some words of Dacian origin designating leather objects or involving leather: hat, vamp, colt, billy goat, collar, strap, quarter, to pull tight, wild boar. Some of the Romanian words with an unknown etymology preserved until today refer to leather objects (twilled cloth, bladder, bagpipes, awning, to rein, helmet) and tools (stitch, bodkin). However, the Latin linguistic heritage regarding hide processing is richer: leather and leatherworker, hair, halter, girth, belt, to take shoes off, leash, bellows, awl, saddle, sheath, boot leg [2].

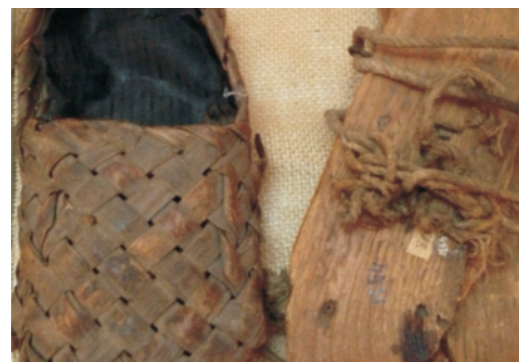

În şantierele arheologice de la Capidava Constanţa, Vaslui - Moldova, Dăbâca - Cluj, Alba-lulia sau Noslac - Transilvania, uneltele din ce în ce mai perfecţionate, ca şi resturile dintr-un cojoc de mâner şi o opincă sunt dovezi certe ale continuităţii acestor meşteşuguri, prelucrarea pieilor şi confecţia îmbrăcămintei şi încălţămintei din piele.

În afara culturii materiale, tezaurul limbii române oferă şi el preţioase mărturii privind terminologia esenţială din domeniul pielăriei, confecţionării vestimentaţiei şi a încălţămintei. Cuvinte de origine dacică, indicând obiecte de piele sau implicând piele sunt: căciulă, căpută, mânz, ţap, zgardă, baier, carâmb, îngurzi, mistreţ. Dacă se reţin cuvinte româneşti, a căror etimologie a rămas până azi necunoscută, se poate constata că dintre acestea multe se referă la obiecte din piele: zeghe, burduf, cimpoi, coviltir, dârlogi, chivără, iar altele, precum cusătură şi suvac, se referă la unelte. Mult mai bogat este în limba română patrimoniul lingvistic de origine latină, romană, privitor la prelucrarea pieilor sau implicat în această ocupaţie: piele şi derivatul sau pielar, câr, căpăstru, chingă, curea, descălţa, frâu, foale, sulă, şa, teacă, tureac etc. [2].

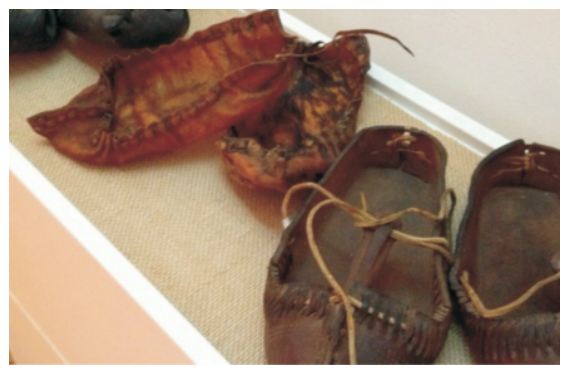

Figure 28. Monk's footwear (left) and peasant sandals (right),

Ethnographic Museum of Transylvania - Cluj-Napoca

Figura 28. Încălţămintea călugărilor (stânga) şi opincile ţărăneşti (dreapta), Muzeul Etnografic al Transilvaniei - Cluj-Napoca

Both the material vestiges demonstrating hide processing activity on the Romanian territory, and the Romanian linguistic thesaurus reveal the continuous development of the trades related to hide processing, resulting from the Romanian people's continuity in the hearth of their Dacian ancestors.
Atât vestigiile materiale care atestă prelucrarea pieilor pe teritoriul României, cât şi tezaurul lingvistic românesc relevă în egală măsură continuitatea multimilenară a unor meşteşuguri, deopotrivă cu însăşi continuitatea poporului român în vatra strămoşilor săi geto-daci. 


\section{CONCLUSIONS}

In conclusion, the abundance of the archaeological vestiges on the current Romanian territory can be said to expect experts in garment culture, involving footwear, to reveal and call the public's attention to the cultural, technical and artistic characteristic features of these objects which are actual testimonies of old historical times preserving valuable creative elements for the future designers.

\section{CONCLUZII}

În concluzie se poate spune că bogăţia mărturiilor arheologice de pe teritoriul României de astăzi aşteaptă specialiştii în cultura veşmântului, inclusiv ai încălţămintei, pentru a pune în valoare, a aduce în atenţia publicului modern specificul cultural, tehnic şi artistic al acestor obiecte care sunt reale mărturii ale unei vechi istorii care mai păstrează încă valoroase elemente de creativitate pentru designerii viitorului.

\section{REFERENCES}

1. Dumitrescu, V., Prehistoric Art in Romania (in Romanian), 1974, Bucharest.

2. Deselnicu, M., Olteanu, S., Teodorescu, V., History of Leather processing on the Romanian Territory (in Romanian), 1984, Technical Press, Bucharest.

3. Comşa, E., Anthropomorphic Figurines in the Neolithic (in Romanian), 1995, Bucharest.

4. Andreescu, R.R., Anthropomorphic and Zoomorphic Plastic from Gumelniţa (in Romanian), CIMEC - Program „Archaeological publications", 2001.

5. Moise, D., Radu, V., Bălăşescu, A., Aspects of Livestock Economy in the Gumelniţa Culture Communities (in Romanian), CIMEC-Program „Archaeological publications”, 2001.

6. Daicoviciu, C., Ferenczi, A., Dacian Settlements in the Orăştie Mountains (in Romanian), 1951.

7. Crisan, I.H., Geto-Dacian Civilization (in Romanian), 2007, Dacica Press. 